\title{
Globalization and Historiography
}

\author{
Juan Manuel Santana Pérez
}

History as a theoretical discipline is being conditioned by economic globalization that is fast becoming a new ideology. The French École des Hautes Études en Sciences Sociales and the British school of thought, which emphasize historic materialism, have had a considerable impact on world historiography. Many historians have studied in these two centers and either returned to their countries of origin or remained in the United States or Europe, continuing their research in related areas. Generally, historiography has developed a northwestern European theoretical bias. Correlations exist and positivist influences may be identified concerning historical materialism based on the French model developed in the Annals School.

At the close of the twentieth century, globalization seems to be the most widely held scientific perspective, thus reorienting all the History-related Social Sciences. Finance capital dominates this new scenario; rather than questioning such dominion, this may be seen as a long-sought panacea, as capital intervention freely crosses borders.

Some historians have rightly pointed out that by intensifying this shift toward globalization, historians are in danger of falling prey to the cold logic of hegemonically centered capital. This is not merely the threat of economic submission, but an attendant cultural overpowering that denies differences in the name of the globalizing process. In this process a select few dominate the many (Zarth, 1996:3).

Ironically, along with globalization of discourse, major philosophical arguments in the 1990s arose to oppose any project aimed at shoring up inequalities in Europe, with two different speeds in devel-

This chapter was translated from Spanish by David Shea, Lecturer in Translation, Universidad de Las Palmas de Gran Canaria; revision by L. J. McCrank. 
opment. In the American sphere two independent worlds, each with their own benefits, were positioned in the north. Distinguished historians who support the notion of socialization, such as Santos Juliá (1990: 25-29), defend these same economies as possible reconstructions of an overall history. They predict that the future of the History profession depends on shedding coherent total interpretations, but also on being satisfied with partial explanations. Others (Barros, 1996: 69) maintain that History, to renew its social and scientific credibility, must recover "the principle of globality in the face of rampant fragmentation of the discipline." Rather than true globalization, however, we seem to have a "McDonald's-ization" or "Coca-Colaization" process. Historians need to recover an interpretative mode with a global attitude that explains the world as a whole, so it does not seem utterly incomprehensible.

This thought is linked to the approach taken by Michel Foucault (1981) approach to the particular. Systemic skepticism was vital in Foucaultian thinking in the face of anthropological generalities. He denied the existence of a single form of the human being, i.e., the universal "human" through which the historian could emphasize the contingency of different concepts of the human condition in terms of certain practices and technologies of one's self. This negates the possibility of History and favors partial history or histories. Faced with the profound historicity of these ideas, the universalist stance defended by J. Habermas (1991) leads inevitably to a theory of society's evolution without involving the species in hypostation of individual behavior through the reality of human communication.1 Globalization needs to be questioned since it forms part of the global market system, with critical transnational sectors and infrastructures, and its privatization of public property. Globalization is not a transformation toward a general system, and so we believe it would be more prudent to speak of globalism rather than globalization.

At the close of the twentieth century, the economic politics of the state have taken a historical turn with far-reaching consequences (Echeverria, 1995: 40). We now have an economic model and an ideological base that justifies this, which perpetuates the dependency of poorer nations on richer ones. This situation divides countries further. Meanwhile international institutions do little but ratify the politics of capital. Continuance of such a situation tears at the political, cultural, and economic fabric of national societies, assimilating a small sector while exploiting the majority (Petra, 1997: 79).

An earlier era, at the beginning of the twentieth century, had been dominated by the idea of progress. Indeed, this period came to be known as Progressive and was related philosophically and historiographically to Positivism, which opposed revolution in favor of the triumphant bourgeois belief in scientific and technological advancements (Villar, 1964: 449-493; Carr, 1976: 11ff). Progressivism survives in the idea that History, to be a science, must emulate the Natural Sciences. It should be precise, have a real or experimental basis, and provide some process of verification. This has led to the idea that the only aspect of human subjectivity is historical fact.

Positivists aimed at constructing a rigorous History that adhered strictly to historical facts. From its beginnings, Positivism limited its range of study about the human past to those individual events that could be recognized through careful heuristic study. In other words, this had to be done through a consideration of objective, external sources (Carbonell, 1976). The foremost Positivist ideologue, Auguste Comte (1985 ed.), believed Capitalism would spell the end of history. To establish social harmony in this context, he proposed the formation of a new religion in which the worship of God was substituted by the veneration of an abstract superior being. This erudite, conservative Positivism stemming from these early theories became widely accepted in academic circles and dominated historical interpretation for a generation or more. As historians limited themselves to facts based on historical documents, Positivism became entrenched and proved very restrictive, favoring such topics as Politics and Diplomatic History. The main characteristics of historical Positivism, then, include the favoring of political, diplomatic, and military facts; an almost exclusive focus on European and Western History; and, despite great erudition, an almost unquestioning reliance on fact without adequate interpretation.

This European-based, Western-style development has been taken to be the preferred model for civilization and progress, thus forming the ideological framework for History. This did not reproduce simple copies, because no two histories were the same, but there were similar characteristics in the intellectual underpinning of Positivism in most historiographic writing. 
Within the limits of this fact-based history, the past serves as a model for the present. Such History does not present a well-developed notion of progress. Instead, the past is generally considered better than the present, and its history is taken as a point of reference for current generations. Our forebears were seen as those who forged the State, rather than focusing on the constant maintenance of the State or history to the present. Thus History became a chronicle of national heroes in the past. Moreover, the only acceptable historical subjects were those who took a leading role in politics or war. In this paradigm, the role of historians in such traditional historiographic work is thus limited because they reject anything that does not form part of the document-based description of events. They are left to transmitting historical events as taken from accepted sources. They narrate history without interfering in its course.

When this model entered a period of insurmountable crisis, another clearly articulated system came into being which provided coherent justification for the dominant social relations. This "Developmentalism" maintained that all countries could and should develop; thus, all poor nations were said to be developing. Any rejection of the notion was scant because of an unspoken or assumed imperative that everyone needed to push forward with development, to a stage where everyone would be happy, and problems would cease to exist. This era saw great migrations from the country to the city, where people looked for their place in this development scheme. Even the most advanced sectors were convinced that by tightening their belts their problems would soon be over. They would be developed, because they were developing. CEPAL was thus established, replete with its theories of inequalities of development. In historiography, this same socioeconomic thinking led to the academic dominance of the Annales School.

A new general approach to History also meant a new theoretical and methodological conception. The évènementielle mentalité or event-centered view of History and the factual scientificism of Positivism were thus rejected when historical thought became more developmental in perspective. More historical synthesis was proposed, along with a logical tendency toward interdisciplinary study, particularly regarding Sociology. Historic causality began to be accepted, as structural causality replaced the genetic causality associated with Positivism. Whereas Historicism's chronological concatenation of events went no further than immediate, superficial causes, new trends in History would beckon reinvestigation of these causes in the basic and more profound structures of the historic process.

There seems little doubt that these historiographic changes, intellectual revolutions really, were stimulated by simultaneous transformations in European and world society at large. Industrial advances, the growing significance of social struggle that led to the Russian revolution, and the consolidation of the Socialist movement are all elements that explain the renewed interest in Historicism at the start of the twentieth century. Increasing economic concern, particularly in the wake of the 1929 stock market crash, followed changes in the social and economic order. Furthermore, a certain level of apolitical intellectualism led to the rejection of traditional History based only in Politics (Dossé, 1988: 16). The Annales school in France was underwritten by the Rockefeller Foundation. This support was justified by the expressed belief that better knowledge of the world's problems "would provide better social control for the good of all" (Mazon, 1988).

The Annales school endeavored to place structures into a historical framework to formalize the concept of "Civilization" to capture the essential features of social formation at the highest level. From this definition, disparate cultures and economic systems could be compared to fashion an overall historical picture. Regional studies also came into vogue. In these studies, through the analytical demarcation of regions, historians attempted to group different historical planes into a single study. Such an approach was championed by European social democrats who sought to reconciliate social classes. They relied on external funding such as Rockefeller and Ford Foundation grants, Marc Bloch Association support, and Guggenheim scholarships.

In the 1980s, these hopes for total conciliation were dashed. Indeed, the crisis was of such magnitude that these years came to be known as the "lost decade." Many historians had been searching for a panacea that did not exist, and History was left in ruins. The unifying concept of continuous "Development" became as mythically elusive as El Dorado (Rivero, 1988: 158).

Globalization, or Globalism, appeared in the 1990s with encouragement for everyone to create a globalized world. This process would make the so-called Third World nations richer for themselves 
and as markets, so that no one would be left out of this global scenario. Everyone would advance together to the same level. Crisis signs in modern capitalism have already appeared, however, indicating that the benefits derived from production do not find sufficient investment to develop greater productive capacity (Amin, 1999, provides seven essays on the capitalist management of the current crisis). The language employed to describe this situation continues to be a euphemism for differing forms of national and social exploitation. Globalization rhetoric ideologically masks the growing power of United States-based multinationals and their directors who are getting richer and whose companies are exploiting the world market on an unprecedented scale. Thus, globalization has become a key word for the progressive hegemony of U.S. imperialism (Petra, 1999). ${ }^{2}$ This is little more than the globalization of Capitalism, far beyond mere economic considerations (Chesnais, 1994). ${ }^{3}$

Historiography has been affected significantly by social and political conditions in recent years. The fall of the Soviet system, ending the bipolar world, has spelled a setback for all left-wing movements in the so-called Third World, whose strategies were based on the fragile balance between the two superpowers. A powerful nation to counterbalance the United States was crucial for the development of revolutionary movements throughout the world.

Political corruption and the unethical behavior of government leaders have disheartened those who once sought to effect social revolution through bourgeois democracy. Their very institutions are being discredited. The dizzying rate of technological advance has also affected the means of production. These events have caused a crisis in the Left, with significant historiographic consequences. The versions of History produced by the USSR's Academy of Social Sciences, for example, eliminated or misrepresented entire episodes of the pastwith pernicious results. Indeed, almost nothing remains of that model that once sought to transform human beings.

All this has been accompanied by political and economic changes. Gone are any attempts at state intervention or control aimed at a more humane form of Capitalism, as with a social welfare system, at least among wealthy nations. Now governments assume the Chicago School's model of economic Neoliberalism as most desirable. Even the Social Democrats, with their conservative "third way," have wholeheartedly embraced Neoliberalism. This has become the theo- retical basis for their ideological conversion. British Prime Minister Tony Blair (1998: 129) stated that "free trade has proved itself the engine for economic development." 4

Philosophically, we have also seen the advent of Postmodernism taking over where the Modern period ceased. This Postmodern emphasis is characterized by the triumph of both individualism and conservatism. Postmodernity disregards any overall historic vision or project. There are no universal values and Postmodernity vanquishes any conception of History as a single or unified development. Thus, Historiography is going through a crisis precisely because of the diverse intellectual and cultural currents presently being forwarded, resulting in disunity and nonconsensus.

According to one of the leading Postmodernism ideologues in 1979, Jean-Françoise Lyotard (1984), the "great struggles for emancipation" which once formed overall identities are now gone. By "great struggle" he refers to an aim that justifies any means. There are no more ultimate values, he claims, although adding that cultural context is crucial, marked by historical development. However, he recognizes that the study of such historiçal context suggests relativism. In another book Lyotard (1987: 35-50) denies the possibility of understanding History as a single development. He suggests abandoning meta-histories which have lasted for centuries, marked by the idea of indefinite economic development and by the ideal of bourgeois democracy. Lyotard believes that the aspirations dating from May 1968 are dead.

Lipovetsky $(1986: 50,52)$ has analyzed this line of thought and speaks of an Age of Narcissus with reference to the contemporary individual-an emblematic characteristic of today's society. He defends the notion that an anthropological mutation is taking place, transforming the very nature of the individual. This permissive, hedonistic capitalism (as opposed to authoritarian capitalism) manifests itself in the current popularity of bodybuilding and psychotherapies.

Whereas modernity embraces the spirit of industriousness and a positive view of the future, it seems from historical inference that this narcissism heralds the postmodern era. This collective narcissism lacks any notion of tragic nihilism, but is characterized by frivolous apathy, despite the terrible calamities served up daily by the mass media. Perhaps the repetitive nature of these messages has desensitized us to these phenomena. There has been an apparent decline in our val- 
ues, which might be related to the writings of Nietzche, but for him, this was tragedy, and for many today, it is not.

The preceding period could best be described by what Albert Camus (1988) called the "myth of Sisyphus" (as studied by Oviedo Perez, 1992). It is the case of the workers who go to work each day without hope of changing their situation, forever destined simply to "carry the can." Knowledge of this destiny was the antidote for avoiding suicidal tendencies, because they could try to change things through the transformation of their relationship with the means of production. In recent years, life continues to have the same sense of the working classes, but no one commits suicide because the meaning of life is found in the image, the paradigm of contemporary aestheticism, with the increase of beauty and fitness centers.

Today the rage is to live in and for the present: the future does not exist. Only the present is real; the past is simply abandoned. Consequently, some historians now focus their attention on the most immediate History. A new trend involves specializing in the History of the Present-a certain contradiction when speaking of time frames. If we accept the present as a product of the past, this new History would have to date back to the prehistorical era. If the world cannot be considered in its totality, then historical development lacks any universal sense. The same people are fragmented and off-centered, incapable of projecting into the future (Larrain, 1996: 244). Rorty (1991: 253276) criticizes postmodernist thinkers whose inability to conceive of an "us" leads to political apathy. The future has lost all interest, and so "prophetic history" is also abandoned. The exaggerations of this thinking bring on the triumph of living for the moment, total relativism, and political passivity, which may paradoxically lead to a cultural essence. However, society's postmodern fragmentation fits perfectly into the freemarket workings of advanced capitalism.

We are bombarded by messages assuring us that this is the best possible world, as Leibniz (1977 ed.) maintained in his day, although he was subsequently in 1759 ridiculed with Voltairean irony (Voltaire, 1976 ed.). With equal irony, we need only look at Parmenides for assurance that movement does not exist. However, the world does turn, everything changes, and the historian's task is arduous indeed. These campaigns are effective because they have taken on a normative aspect. Any proposal to posit the need for a transformation of a unifying, synthetic, or "single thought" is cast aside. Under such cir- cumstances, how can one provide a worldview, a global perspective, a sense of continuity, or, for that matter, History? This new situation disintegrates the processes of social and political grouping of the oppressed and forces them into a complete crisis of social identity, with all its social implications concerning memory, consciousness, and discourse. It uses current technological powers in communication and transport to try to impose a world recolonization of the imaginary (Quijano, 1996: 3).

In terms of historiography, note that traditional History is becoming accepted again: biographies, narrative histories, military history, diplomatic histories, and politically centered history in the study of power and its relationship with social and symbolic aspects. Of course, this historiographic reaffirmation even of "the military version" also serves to justify spending on armaments, particularly when these industries play an important role in funding the "global market." Diplomacy is replaced by militarism in the relationship that rich nations maintain with the rest of the world. Such developments also have repercussions on methodology and epistemology. Depth seems to substitute for structural considerations in the language of New History. When situated in the world of the mind, it seems less reflexive and more reckless. Some histories try to find a place for politics to explain society while making politics the center of the explanation (Mina, 1993: 63).

Since the mid-1980s, historiography has become enmeshed in a polemic concerning which path to follow: social and economic history have been abandoned in favor of histories of the mind, anthropological and cultural constructs, sometimes known as toumant critique, from the name of the publishing house of Annales (1988: 291-293). This coincides with the history of the imaginary, that is, imaginary representations (images, symbols, and invented realities) that displace previous interests in other mental functions (Barros, 1993: 121). This in itself is not necessarily negative, because from this perspective one can develop Globalism.

For the most part, problem history has also been abandoned, explanatory analysis is vociferously refuted, Sociology is rejected (replaced by Anthropology), and History has been redirected at the description of daily life, of the world of feelings and of the ideological attitudes, leading to Neopositivist factualism even though developed in new fields of study. History is reduced, therefore, in more and more 
cases, merely to the transcription of cultural representations with contextual references.

Some historians, myself included, believe that an enduring description, a minute reconstruction, and presentation of the past for the present consumption do not by themselves constitute historical work. This thinking is connected with the Anglo-Saxon world with a trend that puts social and political events above any cultural phenomena. In this way, we would highlight the conservative intellectual groups, such as represented by Daniel Bell (1969), who see the individual in current society as immersed in the cultural contradictions of capitalism, in which three forms of logic are reconciled: hedonism, efficiency, and equality. The only escape envisioned by Bell is taking recourse in the discarded tradition, the only thing that can provide the individual with existential security currently lacking (Klappenback, 1991). In this context note the most recent work of Francis Fukuyama (1998), where he compares the economies of China, Japan, South Korea, France, Italy, Germany, and the United States with their cultural correlatives and maintains that the dependence between the economy and the State depends on trust relationships created through culture.

Sexual relations, attitudes toward children, death and aging, fear, privacy and intimacy, insanity, and, in more than one case, the risqué and leisure have all been incorporated, overwhelmingly so, into the study of History. They seem constrained by epistemological limitations and often are reduced to curio status, as the past presented for the general diversion of consumer society.

The crisis of historiography at the end of this past century has left a mark on many things. Today there is a total lack of politics and ideology, and hence an absence of theories, while empirical methodologies and professionalism flourish, where a crisis has developed in paradigms, once strong, which are now weak. Some historians who would, in other times, be noted for their affinity toward historical materialism, are today writing fiction and questioning whether History is any more than that. 5 Historian-novelists Garavaglia and Fradkin (1992: 11), for example, recognize only a "thin line" separating the two genre. However, certain glimmers of optimism can be discerned which should theoretically and methodologically strengthen the historiographer's task (Villarruel, 1996: 89-98).
In many current historiographic trends, History loses its concrete references. Local history practically disappears as imported schemes from dominant nations are favored. When these models are adapted to and overlaid on other histories, very different realities are substituted for the local. There is tendency to favor long-term History, in which time seems to stand still. This completely eliminates other time periods and shows general rejection of the possibility of historical change in context. Uprooted from the rest of society, culture is seen as almost unchanging, immune to historical change, constant over time, and, therefore, directly associated to an assumed almost eternal human nature. This has been accompanied by a new Positivism and a throwback to narrative and political history, disregarding the social essence of History. Pour une histoire politique, edited by René Rémond (1988), provides the clearest presentation of such hypotheses. This subject was analyzed by María Cruz Mina (1993: 64), who emphasizes that the political aspects of such a persuasion, and the choice to study politics, may serve conservative ideology. Habermas indicated that historiography has moved toward a narrative system of reference. These historians are not interested in developing a universal history, which Foucault also rejects. Rather they present an alternative concept, a theory of evolution, which "relies on supposed universal structures of consciousness and levels of ordered learning in accordance with the logic of development" (Habermas, 1991: 185).

A dominant idea is that globalization will ultimately destroy the national market, so national capitalism has become obsolete and the role of public powers are diminished (Ramonet, 1997). This is coupled with bewilderment in thinking that the nation-state is an anachronism and that capital crosses national borders with the eventual demolition of protective barriers between national economies (Petra, 1999, thinking of the largest banks and corporations in the United States, Europe, and Japan). Thus, local histories, which were so important in the $1960 \mathrm{~s}-1970 \mathrm{~s}$, lose interest. ${ }^{6}$ Now that Toyota's business figures surpass the Gross National Product (GNP) of Norway, it seems obvious that large companies can finance research to invent their very own version of History if they desire, so they play their strongest hand in current historiography (Lobo, 1991: 217-237). As states cede their main duties and allow their sovereignty to be stripped away, this is not simply submitting to the social, economic, and political evaluation of private interests, but democratic space is being diminished. The states themselves 
are becoming privatized in the international system. Thus we have the growing subordination of national sovereignties to the designs of transnational capital in this process of globalization.

All this has led historians to look to private initiatives, since the state has lost its role in History, with the dismantling of rights, loans, and social services, as well as its ability to study, train, and offer social assistance. The state has often come to defend the belief that the family unit functioned perfectly well in the past; it stresses the importance of public instruction in the development of its citizens' intellectual capacities; it defends individual learning through books; and it tends to see historical change as the product of the individual's mental change. We thus tend to think of culture as possessing an excessive capacity to determine historical processes and changes without taking into account its complete autonomy. The criteria for "scientific reason" and the concept of "objectivity" are considered by postmodern society as mere substitutes for religious and metaphysic images of the Old World by another "rhetoric of truth." Foucault (1981: 25) did not believe in the possibility of an absolute principle, nor in any criterion with a definitive base. Thus he did not consider establishing that any universal norms were positive. Each cultural form of Western civilization has had its system of interpretation, its techniques and methods, its own forms of detecting the language spoken beyond what was being uttered, and the ability to recognize that there are languages within language itself.

As L. Stone (1979/1981: 9-15) put it, referring to this new concept of culture, individual will and culture are significant causes and factors of change "as impersonal forces of the material production and of demographic growth." E. Le Roy Ladurie is more forthright: "Change essentially takes place in the cultural world. A good day is the culture which puts everything away" (quoted by Dossé, 1988: 183).

In this crisis of historiography (in an etymological sense), I would propose to the scientific community some points for debate to foster interpretations for a more hopeful future.

To restore the role of the historian in today's world, History must be linked with a measure of social commitment so that through History we learn that we are free; we should be critical and change the concept of truth from evidence as it has been constructed at one concrete historical moment, and, thus, we should understand it relative to its creation and initial understanding.
Social Sciences have become another arm of power, with specialized methods of domination. They influence the philosophical framework of innovative ways of studying History. The sway of power should remain radically decentralized, making it omnipresent and permeable, so that power is seen as relations distributed asymmetrically throughout society, like dispersed constellations of unequal relations (Hemandez Sandoica, 1995: 175). From a Habermas-based perspective, a new, always critical Social Science must be defended. As Foucault puts it, modern science has become the ideological substrata that legitimizes the status quo in advanced capitalism. Whereas Habermas believed that there was always the possibility of History as a "reconstructive" and liberating science, Foucault sees only a possible delegitimizing action of the historian of ideas. The historian's role as critic is of paramount importance.

Much of what we take to be fixed and universal in our society is little more than the result of precise historical changes. We may perceive the arbitrary nature of institutions thus. What is the space of freedom still available to us, and what changes still need to be made? In this way, History would assume a legitimatizing function. Thus, note the importance of the contextualization of the history of thought within a history of social structures: our thoughts are also social.

Power-and knowledge are inseparably linked. Truth is not beyond power, nor is it powerless. So we must make history of the relationships that unite thought and truth, that is, the history of thought when referring to truth. Foucault (1990: 117) is clearly aware that the system of knowledge which developed in our society is tremendously complex, particularly when we take into account that it possesses sophisticated power structures.

It is this union of knowledge and power that will create human sciences, through vigilance, examining controls, and understanding the norms individuals act by throughout their existence. It would seem obvious then that both the subjects of knowledge as well as the relations of truth are formed in context characterized by economic and political conditions which give them meaning.

Truth does indeed exist. Foucault makes this affirmation in the face of knowledge systems that destabilize objectivity (insanity, power, sexuality). So we propose making History the study of the relations that unite thought and truth; in other words, the history of thought in the case of the notion of truth (Gabilondo, 1990: 182). This can be 
done with no effort to respond to the laws of verification which gov ern History itself, without reducing itself merely to chronicle what happened, i.e., the event, but to study transformations. One of the aims proposed is to show that many of the things forming this landscape and which people consider universal are merely the product of precise historical changes in a larger picture.

Therefore, we should vindicate the validity of any interpretive analysis and defend the right to dissent in the face of monolithic systems which impose mechanically derived answers to questions about the past-or about the future. The history of humanity is not a perfect machine where every consequence has deliberate or even discernible cause, and no one can point to the when, how, or where the grand finale of this endless history might be found. We must be on guard about theories proclaiming the unquestionable triumph of current neoliberal economic positions, and challenge those who view doubt or negation as a sign of craziness, aberrance, or fanaticism. Economic phenomena are neutral and their effects ambivalent. We cannot give in to an ideology of resignation, or buy in to a single-thought system.

Dissenting voices have called for a new model. The revolts in Chiapas provide a paradigmatic example when first, on January 1, 1994, old and new problems emerged and History began to be rewritten (Barros, 1999: 29-52). Along with the historic social and economic exploitation that peasants and indigenous peoples suffered, and continue to suffer, recently neoliberal modernization further aggravated the situation in these communities. This process was marked more by the withdrawal of all state activities in the region, commercially opening the way for internationalization of the internal market in the framework of economic globalization. The economic restructuring that this included, i.e., a new land policy, has negatively affected the Mexican peasant. The region of Chiapas could be seen as a net loser in the globalization process and the application of neoliberal policies, particularly seen in terms of the per capita Gross Internal Product and the Index of Human Development, which have fallen sharply since 1980 (Prieto, 1996: 115-133).

It is crucial to remain critical of dogma, especially among those who hold power by means of its ideological apparatus. We call for a commitment which helps unify philosophical and theoretical approaches with empirical research that touches our everyday lives. We should avoid the too frequent detachment of theory and practice.
Once both are united, it is important to carry this experience to the classroom and share our critical temperament with students. In other words, unite philosophy, research, and teaching. As mass media struggle to keep us forever immobile in the present, unable to transverse the past or think about the future, we must encourage students to aspire to change things for the better, teach them how things fit into History, and help them to see they are capable of achieving change. Indeed, Gramsci's thoughts still can encourage us to be realistic and demand the impossible. We must opt for solidarity, but not only with those in our immediate vicinity in time and place, but also with those who have yet to be born, and with those in the Third World.

A coherent ethical position should relate theory and practice with commitment in our research. All subjects belong to a fixed historical moment and to a larger History. Whereas others have carried their radical extremes beyond the academy for the reconstruction of History, they impact academic History in ways unforeseen: e.g., Marx, Gramsci, Bloch, Negri, and today Subcomandante Marcos of Chiapas.

Dispense with absolutes. One need not recklessly seek the liberating in the nonhistorical, because the very nonroutine, unpredictable, and multidirectional nature of History is itself emancipating. The most important aspect of the historian's job is to defend values of solidarity and justice and, rather than to reach definitive conclusions, to keep searching.

\section{NOTES}

1. Habermas (1991) praises Lawrence Kohlberg's attempt (1988) at developing a theory of moral competences in the Piagetian model, a theory that would be both evolutionary and universalist. We disagree with Habermas on this point and believe that just as we can develop a theory of society, we can also conceive of another for history, as indicated by Aróstegui (1995), p. 158

2. Petra (1999) maintains, "Conventional wisdom concerning globalization tries to sell the public the advantages of this tehsis while eliminating the serious pitfalls. Global economic transformations which have taken place recently are highly complex and not to be taken lightly" (also according to Mendez del Valle, 1999).

3. A more current article by the same author is Chesnais, 1998: 13-33, where his comments on the stance of P. Hist and G. Thompson concerning "the myth of globalization" are particularly relevant and interesting (esp., pp. 15-16).

4. The Iranslation of Blair's book (1998) includes a prologue by the Spanish Socialist Party candidate J. Borrell. For an analysis of Blair's thought, see Garí- 
Monllon (1999: 15). The most important book on this ideological stance is by Anthony Giddens (1994); cf. also his La tercera via (1998).

5. For example, the novel by Garavaglia and Fradkin (1992) which takes place in the eighteenth century and involves characters in events that never took place. They claim these are, if not true, realistic, and that they "fit into the thin line which separates realist fiction from History" (p. 11). Garavaglia, formerly a professor in Italy, Mexico, and Argentina, is currently Director of Studies at the Ecole des Hautes Études en Sciences Sociales in Paris.

6. Local history may be justified by finding local writings, the direct quantitative sources, and even minutes of town council meetings, legal proceedings, etc., which enable historians to understand regional, provincial, and local levels of human affairs. To construct Social History, it is crucial to formulate a synthesis of these regional studies which shows the points of greatest significance, so the scientific rigor of the "larger history" will be properly reinforced.

\section{BIBLIOGRAPHY}

Amin, Samir (1999). El capitalismo en la era de la globalization. Barcelona: Paidós Iberica.

Amales (1988) "Histoire et Sciences Sociales. Un tournat critique?" Annales: Economies, Sociétés, Civilisations, Marzo-Abril: 291-293.

Aróstegui, J. (1995). La investigación histórica: Teoría y método. Barcelona: Crítica.

Barros, Carlos (1993). "Historia de las mentalidades, historia social." Historia Contemporánea (Universidad del País Vasco, San Sebastián: Universidad del País Vasco), 9.

(1996). Historiografía fin de siglo. Santiago de Compostela: Tórculo.

(1999). "Chiapas y la escritura d ela historia." Contexto and Educaçâo. Revista de Educa̧̧âo em América Latina y El Caribe, Ijuí (Brasil), 14 (54, AbrilJunio): $29-52$.

Bell, Daniel (1964). El fin de las ideologías. Madrid: Editorial Tecnos.

Blair, Tony (1998). La tercera vía. Madrid: El País-Agilar.

Camus, Albert (1988). El mito de Sísifo. Madrid: Alianza.

Carbonell, Charles-Olivier (1976). Histoire et historiens, une mutation idéologique des historiens français, 1865-1885. Toulouse: Privat.

Carr, Raymond (1978). ¿Qué es la historia? Barcelona: Editorial Seix Barral.

Chesnais, François (1994). La mondialisation dlt capital. París: Syros.

- (1998). "A mundializaçao do capital e acumulaçao financeira neoliberal:

Elementos de ruptura." O Olho da história (Salvador de Bahía), 1(5): 13-33. Comte, Auguste (1985). Discurso sobre el espínitu positivo. Madrid: Alianza Editorial. Dossé, François (1988). La historia en migajas. Valencia: Ed. Alions el Magnamino.

Echeverria, Bolívar (1995). Las ilusiones de la Modernidad. México City: Universidad Nacional Autonoma de Mexico.

Foucault, Michel (1981). Nietzche, Freud, Marx. Barcelona: Anagrama
(1984). La verdad y las formas juridicas. México: Gedisa.

(1990). Tecnologias del yo. Barcelona: Paidós.

Fukuyama, Francis (1998), La confianza. Barcelona: Ediciones B.

Gabilondo, A. (1990). El discurso en acción: Foucault y una ontología del presente. Barcelona: Anthropos.

Garavaglia, Juan Carlos; Fradkin, Raúl (1992). Hombres y mujeres de la colonia. Buenos Aires: Universitaria.

Garí-Monllort, Domingo (1999). "Comentario a la Tercera vía de Blair." La Tribuna de Canarias, Las Palmas de Gran Canaria, 28 Marzo: 15.

Giddens, Anthony (1994). Más allá de la derecha y la izquierda. Madrid: Cátedra.

- (1998). La tercera vía: La renovación de la social democracia. Madrid: Taurus.

Golub, Philip S. (1998). "Un giro en la historia de la globalization." In Albiñana, Antonio (ed.), Pensamiento crítico vs. pensamiento único. Madrid: Debate.

Habermas, J. (1996). Conciencia moral y acción comunicativa. Barcelona: Península.

Habermas, J.; Muñiz, Jaime N; Garcia Cotarela, Ramón. (1981/1985). La reconstruccion del materialism histórico. Madrid: Taurus.

Hernández Sandoica, E. (1995). Los caminos de la Historia. Cuestiones de historiografia y método. Madrid: Síntesis.

Klappenbach, A. (1991). Etica y posmodernidad. Alcalá de Henares: Universidad de Alcalá de Henares.

Kohlberg, L. (1958). The Development of Modes of Moral Thinking and Choice in the Years 10 to 16 . Thesis. Chicago: University of Chicago.

Juliá, Santos (1990). "El historiador escéptico." In José Manuel Azcona (ed.), Debates por una historia viva. Bilbao: Universidad de Duesto.

Larrain, J. (1996). Modernidad, razón e identidad en América Latina. Santiago de Chile: Editorial Andrés Bello.

Leibniz, Gottried Wilhelm (1977 ed.). Nuevos ensayos sobre el entendimiento humano. Madrid: Editora Nacional.

Lipovetsky, Gilles (1983; 1986). La era del vacio: Ensayos sobre el individualismo contemporáneo. Barcelona: Anagrama.

Lobo, Eulália (1991). "História Empresarial." In Cardoso, C.F.S. and Vainfas, R., Domínios da Histónia: Ensaios de Teoria e Metodologia (pp. 217-237). Río de Janeiro.

Lyotard, Jean-François (1979; 1984). La condición postmodema: Informe sobre el saber: Madrid: Cátedra. Translated from the first French edition, published in Paris by Minuit, 1979.

- (1987). El entusiasmo: Critica kantiana de la historia. Barcelona: Gedissa.

Mazon, Brigitte (1988). Aux origines de l'Ecole des hautes études en sciences sociales: Le role da mécénat américain (1920-1960). Paris: Editions du Cerl.

Menéndez del Valle, Enilio (1999). “Globalization o desarrollo?” El Pais, 8 Oct. 
Order a copy of this book with this form or online at:

http://Www.haworthpress.com/store/product.asp?sku=5411

Mina, María Cruz (1993). "En torno a la nueva historia política francesa." Historia Contemporánea (San Sebastián), 9.

Oviedo Pérez, Diego (1992). El mito de Sísifo de Albert Camus. Sevilla. Petri. James (1979). "La izquierda devuelve el golpe." Ajoblanco, 4 (spring).

-_ (1999). "El fin del mito de la globalization." El Mundo, 25 enero.

Prieto, Osvaldo (1996). "Globalization y democracia en América Latina: Lá insurrección chiapaneca y el neoliberalismo mexicano." Memoria Latinoamericana: Revista de Investigación Histórica y Sociológica, Río Cuarto (Argentina), Diciembre: 115-133.

Quijano, Aníbal (1996). "La Historia recien comienza." Universidad y Sociedad (Lima), 6 (Dec.), sp. issue 3.

- (1999). "Globalization o imperialismo USA." El Mundo, 3 Marzo.

Ramonet, Ignacio (1997), "Regimenes globalitarios." Le Monde Diplomatique, 2 (15, Enero)

Rémond. René (ed.) (1988). Pour une histoire politique. Paris: Seuil.

Rivero, Oswaldo de (1988). El mito del desarrollo: Los países imiables en el siglo $X X I$. Lima: Mosca Azul Editores.

Rorty, R. (1991). "Habermas y Lyotard sobre la posmodernidad." In Bernstein, R.J. (ed.), Habermas y la modernidad (pp. 253-276). Madrid: Cáledra.

Stone, Lawrence (1979/1981). "The Revival of the Narrative: Reflections on a New Old History." Past and Present, 85: 3-24. Included in his Past and Present, London: Routledge, 1983. $\frac{1}{190 .}$ (1995). "The Future of History." Historia a Debate, Barros, C. (ed.), 1: 177 -

Vilar, Pierre (1964). "Marxismo e Historia en el desarrollo de las Ciencias Sociales. Para un debate metodológico." In Crecimiento y Desarrollo (pp. 449-493). Barcelona: Ariel.

Villaruel, José C. (1996). "El spleen: Modernidad y pensamiento silvestre." In Barros, Carlos and Aguirre Rojas, Carlos (eds.), Historia a Debate: América Latina (pp. 8998). Santiago de Compostela: Historia a Debate.

Voltaire (1976 ed.) Candide ou l'optimisme. Paris: Hachette.

Zarth, Paulo Afonso (1996). "Apresentaçao." Regionalizaçao e Globalizaçao. IjuíRío Grande do Sul (Brasil). Based on a presentation entitled "Sobre a problemática regional aportes para o futuro,"at the IV Encontro de Cientistas Sociais held in Ijuí in May 1996. 